\title{
Rosai-Dorfman Disease Presenting as A Breast Mass
}

\author{
Ding Dai ${ }^{1 *}$, Qi Cai ${ }^{2 *}$, Nasreen A Vohra ${ }^{3}$, Jan Wong ${ }^{3}$, Zsuzsanna P Therien ${ }^{4}$, Karlene Hewan-Lowe ${ }^{1}$ and Ann Sutton ${ }^{1}$ \\ ${ }^{1}$ Department of Pathology and Laboratory Medicine, East Carolina University, USA
}

${ }^{2}$ Department of Pathology, UT Southwestern Medical Center, USA

${ }^{3}$ Division of Surgical Oncology, East Carolina University, USA

${ }^{4}$ Eastern Radiologists, USA

Submission: February 20, 2019; Published: February 28, 2019

*Corresponding author: Ding Dai, Department of Pathology, East Carolina University, USA and Qi Cai, Department of Pathology, UT Southwestern Medical Center, USA

\begin{abstract}
Rosai-Dorfman disease (RDD) is an idiopathic, benign proliferation of histiocytes that can be present in multiple organs such as lymph node, skin, soft tissue, orbit, central nerve system and bone; however, it rarely occurs in the breast. In general, RDD is a painless, firm and poorly defined lesion, which can radiologically mimic a breast cancer and is therefore an important consideration. The diagnosis of breast RDD is challenging, especially on a small biopsy specimen. We report a unique case of breast RDD with a literature review including common presentation, differential diagnosis, and recommended management. A high index of suspicion for this rare entity is essential to render a correct diagnosis, thereby avoiding unnecessary diagnostic tests and treatment.
\end{abstract}

Keywords: Rosai-Dorfman Disease; Breast Cancer; Emperipolesis

\section{Introduction}

Rosai-Dorfman disease (RDD), or sinus histiocytosis with massive lymphadenopathy, is an uncommon, benign, histiocytic proliferative disorder with poorly defined pathogenesis. Initially, it was described by Rosai and Dorfman in 1969 [1]. The characteristic histology features a S100 positive histiocytic proliferation with lymphoplasmacytic infiltration and the hallmark finding of emperipolesis [1,2]. RDD is often seen in children and young adults, with a slight propensity for males, and may occur in any part of the body. Usually, RDD presents with painless lymphadenopathy predominantly in cervical

lymph nodes and often bilateral [1]. Extranodal RDD accounts for nearly $40 \%$ of all RDD cases, and most commonly is seen in the skin, upper respiratory tract and bone [3]. The breast is rarely involved in RDD. So far, approximately 34 cases of breast RDD are reported in the English literature. RDD of the breast usually presents as an asymptomatic, solitary mass lesion with irregular borders and increased vascularity on radiographic study, which may mimic invasive breast cancer. Due to its rarity, pathologic diagnosis of breast RDD is challenging, especially in a small biopsy sample with limited tissue. In this report, we discuss a case of breast RDD with a literature review [4-10].
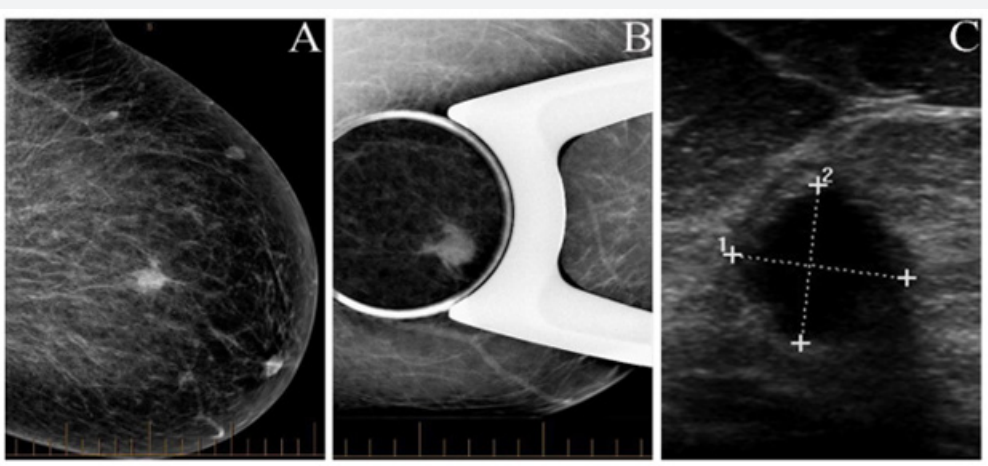

Figure 1: Imaging study in the left breast mass. A. Sonogram showing an irregular, solid, wellcircumscribed, hypoechoic lesion. B. Screening mammogram demonstrating an irregular mass lesion with high density. C. Mammogram with spot compression displaying a well-defined mass lesion with an infiltrating margin. 


\section{Case Report}

A 42-year-old asymptomatic female underwent a routine screening mammogram. Imaging study revealed a dense mass lesion with irregular borders in the upper outer quadrant of the left breast (Figure 1A). Subsequently, it was confirmed by spot compression mammogram (Figure 1B). The ultrasound examination showed a $1.1 \mathrm{~cm}$ hypoechoic mass with irregular margins at 11 o'clock position (Figure 1C). The patient underwent core needle biopsy and the standard of care for a Breast Imaging-Reporting and Data System (BIRADS) 4 lesion. The final pathological diagnosis for the core needle biopsy was Rosai-Dorfman Disease. Subsequently, a lumpectomy was performed [11-13].

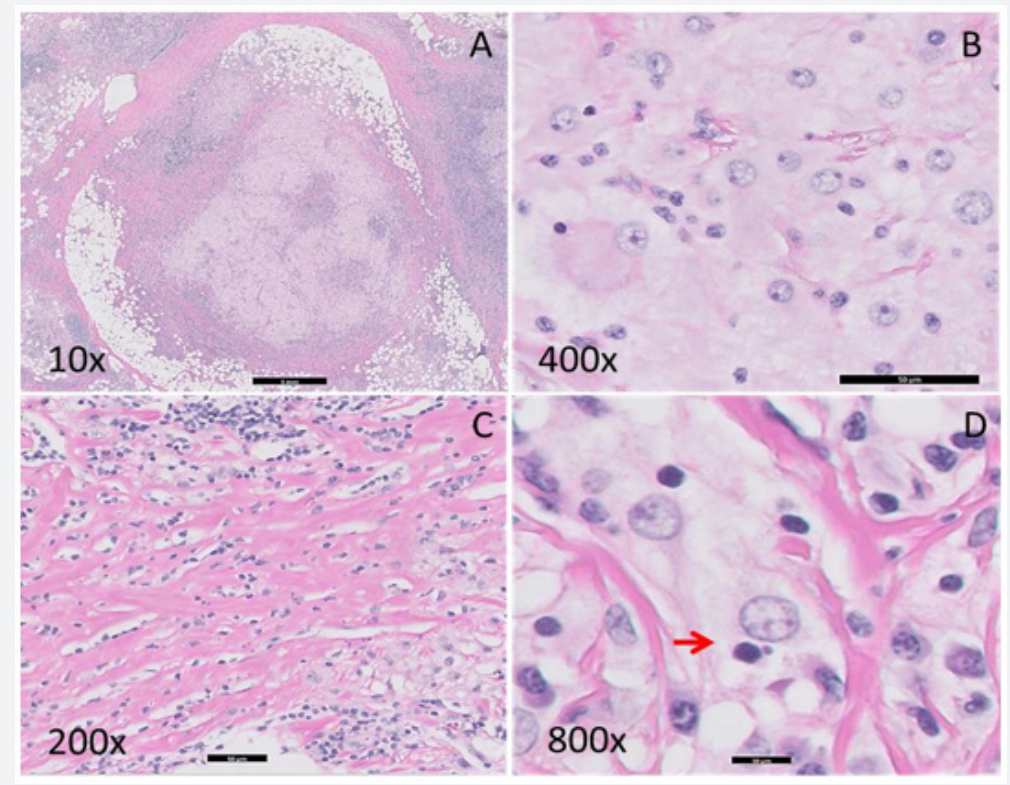

Figure 2: Histopathologic findings of the breast mass. A. Nodular proliferation of histiocytes with dense lymphoplasmacytic infiltration and peripheral thick hyalinizing fibrotic bands $(10 \mathrm{X})$. B. Histiocytes with a round nucleus, inconspicuous nucleolus and abundant pale and foamy cytoplasm $(400 \mathrm{X})$. C. Dense lymphocytic infiltration and thick collagen bundles $(200 \mathrm{X})$. D. Emperipolesis of a lymphocyte by the large histiocyte as indicated by arrow " $\rightarrow$ " (800 X).

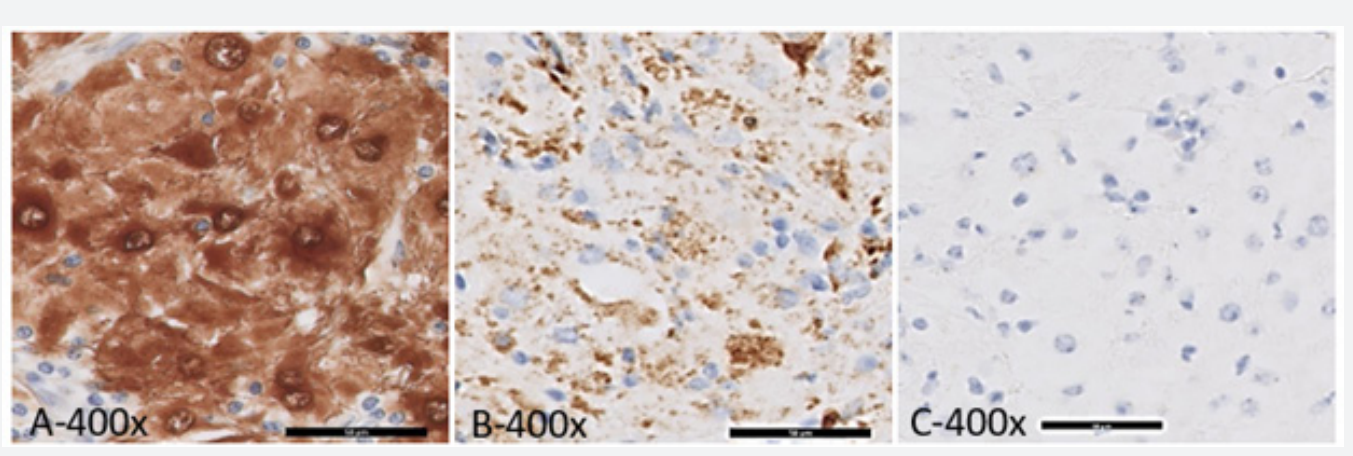

Figure 3: Immunohistochemical study of the breast mass (400 X). A. S100, B. CD68 and C. CD1a.

Gross examination of the lumpectomy specimen showed a $1.5 \times 1.2 \times 1.0 \mathrm{~cm}$, white-tan, firm, and ill-defined mass with no necrosis identified. Histologic examination of the mass revealed a histiocyte proliferation in a sheet-like and nodular pattern admixed with dense hyalinized collagen bands (Figure 2A \& 2C). Large polygonal histiocytes form syncytia which displayed abundant pale and foamy cytoplasm with indistinct cell borders. Intermediate to large round vesicular nuclei were present, usually eccentrically located with small conspicuous nucleoli (Figure 2B). Scattered histiocytes with engulfed intact lymphocytes and plasma cells were identified, indicative of emperipolesis (Figure
2D). A dense lymphoplasmacytic infiltrate was present focally (Figure 2A,2C). The histiocytic mass infiltrated into adjacent adipose tissue and involved the surgical resection margin. The immunohistochemical study of S100, CD1a, CD68, CD20, $\mathrm{CD} 3$, and CD5 was performed on the resection specimen. The lesional histiocytes displayed diffuse strong positivity for both S100 (Figure 3A) and CD68 (Figure 3B), and were negative for CD1a (Figure 3C). CD3, CD5 and CD20 stains demonstrated the presence of a mixed population of $\mathrm{B}$ and $\mathrm{T}$ lymphocytes. Kappa and lambda in-situ hybridization showed the presence of polyclonal plasma cells. No pancytokeratin positive epithelial 
component was identified. Modified Ziehl-Nelson, Gomori's Methenamine Silver (GMS) and Periodic acid- Schiff (PAS) stains were negative for mycobacteria, fungi, or other organisms. The patient has been followed for three years without any evidence of recurrence or malignant transformation on clinical exam or imaging studies [14,15].

\section{Results}

Figure 1 to Figure 3

\section{Discussion and Conclusion}

RDD more commonly involves in lymph nodes where the characteristic features for RDD are sinus expansion by histiocytes, prominent emperipolesis and histiocyte proliferation resulting in lymphadenopathy. This constellation of findings is not seen in extranodal RDD, such as breast RDD, due to increased fibrosis and absence of sinus architecture which may make the diagnosis more challenging. Diagnosis of breast RDD by a core needle biopsy is complicated by limited tissue which may not reveal the characteristic features. In our case, a core needle biopsy showed distinct histiocyte-rich and lymphocyte rich areas with rare emperipolesis. Immunohistochemical studies support the diagnosis [16]. A few reported cases were successfully diagnosed by fine needle aspiration [7,8,17-19] based on identification of the hallmark feature of emperipolesis.

Breast RDD usually presents as a painless, palpable mass lesion, which may be found incidentally on routine screening mammography... So far, there are 34 cases of breast RDD reported (Table 1) in English journals. The age ranged from 15 to 84 years with a mean age of 53.2 years. Breast RDD can occur in both females and males with a female predominance (85\%). The ratio of female to male was 5.8 to 1 . Among those reported cases of breast RDD, 4 cases involved skin, showing deep dermal and subcutaneous lesions [4-7]. Three cases involved intramammary lymph nodes [8-10]. Twenty-seven cases presented with parenchymal RDD (Table 1).

Table 1: Summary of reported Rosai-Dorfinaa Disease.

\begin{tabular}{|c|c|c|c|c|c|c|c|}
\hline References & Age & Sex & Laterality & Other Sites & Treatment & Recurrence & Follow-Up \\
\hline Our Case & 42 & $\mathrm{~F}$ & $\mathrm{~L}$ & No & Excision & No & $12 \mathrm{mo}$ \\
\hline El-Attache, et al. [35] & 55 & M & $\mathrm{R}$ & No & Excision & Yes & $3 \mathrm{yr}$ \\
\hline Delaney, et al. [34] & 63 & $\mathrm{~F}$ & $\mathrm{R}$ & No & No & No & Yes \\
\hline Zhou, et al. [33] & 71 & $\mathrm{~F}$ & $\mathrm{R}, \mathrm{M}$ & No & Excision & No & $\mathrm{U}$ \\
\hline Parkin, et al. [32] & 56 & $\mathrm{~F}$ & $\mathrm{~L}$ & No & No & No & $3 \mathrm{yr}$ \\
\hline \multirow{2}{*}{ Mantilla, et al. [29] } & 67 & $\mathrm{~F}$ & $\mathrm{U}$ & No & Excision & No & $\mathrm{U}$ \\
\hline & 59 & $\mathrm{~F}$ & $\mathrm{U}$ & Yes & No & NA & $3 \mathrm{yr}$ \\
\hline $\mathrm{Fu}$, et al. [15] & 78 & $\mathrm{~F}$ & $\mathrm{R}$ & No & Excision & $\mathrm{U}$ & $\mathrm{U}$ \\
\hline cha, et al. [11] & 62 & $\mathrm{~F}$ & $\mathrm{R}$ & No & Excision & No & $10 \mathrm{mo}$ \\
\hline Baladandapan, et al. [10] & 59 & M & $\mathrm{L}, \mathrm{M}$ & No & Excision & $\mathrm{U}$ & $\mathrm{U}$ \\
\hline Gwin, et al. [31] & 68 & $\mathrm{~F}$ & $\mathrm{~B}, \mathrm{M}$ & Yes & No & $\mathrm{U}$ & $\mathrm{U}$ \\
\hline Tenny, et al. [28] & 64 & $\mathrm{~F}$ & $\mathrm{R}$ & Yes & Excision & Yes & $11 \mathrm{mo}$ \\
\hline Bansal, et al. [7] & 35 & $\mathrm{M}$ & $\mathrm{R}$ & No & No & No & $16 \mathrm{mo}$ \\
\hline Wu, et al. [14] & 33 & $\mathrm{~F}$ & $\mathrm{R}$ & No & Excision & Yes & $29 \mathrm{mo}$ \\
\hline \multirow{3}{*}{ Morkowski, et al. [16] } & 53 & $\mathrm{~F}$ & $\mathrm{~L}$ & No & Excision & No & $5 y r s$ and $10 \mathrm{mo}$ \\
\hline & 45 & $\mathrm{~F}$ & $\mathrm{~L}$ & No & Excision & No & $14 \mathrm{mo}$ \\
\hline & 54 & $\mathrm{~F}$ & $\mathrm{R}$ & No & Excision & No & $4 \mathrm{yrs}$ \\
\hline da Silva, et al. [12] & 50 & $\mathrm{~F}$ & $\mathrm{~L}$ & No & Excision & No & Yes \\
\hline Perera, et al. [6] & 23 & M & $\mathrm{L}$ & No & Excision & No & $3 \mathrm{mo}$ \\
\hline Pham, et al. [32] & 53 & $\mathrm{~F}$ & $\mathrm{~L}$ & No & No & NA & $\mathrm{U}$ \\
\hline Kuzmiak, et al. [13] & 30 & $\mathrm{~F}$ & $\mathrm{R}$ & No & Excision & $\mathrm{U}$ & $\mathrm{U}$ \\
\hline \multirow[t]{2}{*}{ Ng, et al. [9] } & 61 & $\mathrm{~F}$ & $\mathrm{R}$ & No & Excision & No & $6 \mathrm{mo}$ \\
\hline & 40 & $\mathrm{~F}$ & $\mathrm{R}$ & No & Excision & No & $1 \mathrm{mo}$ \\
\hline Hummel, et al. [19] & 52 & $\mathrm{~F}$ & $\mathrm{~L}$ & Yes & Excision & No & $18 \mathrm{mo}$ \\
\hline soares, et al. [18] & 65 & $\mathrm{~F}$ & $\mathrm{~B}, \mathrm{M}$ & No & No & NA & $4 \mathrm{yr}$ \\
\hline \multirow{4}{*}{ Green, et al. [4] } & 27 & $\mathrm{~F}$ & B, M & Yes & Excision & No & $6 \mathrm{mo}$ \\
\hline & 15 & $\mathrm{~F}$ & $\mathrm{U}$ & Yes & Excision & $\mathrm{U}$ & $\mathrm{U}$ \\
\hline & 84 & $\mathrm{~F}$ & $\mathrm{~B}, \mathrm{M}$ & Yes & Excision & $\mathrm{U}$ & Died after 2 mo \\
\hline & 56 & $\mathrm{~F}$ & $\mathrm{~L}$ & No & Excision & No & $5 \mathrm{yr}$ \\
\hline
\end{tabular}


Journal of Gynecology and Women's Health

\begin{tabular}{|c|c|c|c|c|c|c|c|}
\hline & 69 & $\mathrm{~F}$ & $\mathrm{R}$ & No & Excision & $\mathrm{U}$ & $\mathrm{U}$ \\
\cline { 2 - 8 } & 48 & $\mathrm{~F}$ & $\mathrm{R}$ & No & Excision & $\mathrm{U}$ & $\mathrm{U}$ \\
\cline { 2 - 7 } & 54 & $\mathrm{~F}$ & $\mathrm{R}$ & No & Excision & $\mathrm{U}$ & $\mathrm{U}$ \\
\hline Hammond, et al. [17] & 67 & $\mathrm{~F}$ & $\mathrm{U}$ & No & Excision & No & $6 \mathrm{mo}$ \\
\hline Mac-Moune Lai, et al. [5] & 34 & $\mathrm{M}$ & $\mathrm{L}$ & No & Excision & $\mathrm{U}$ & $\mathrm{U}$ \\
\hline Perez-Guillermo, et al. [8] & 71 & $\mathrm{~F}$ & $\mathrm{~B}, \mathrm{M}$ & No & Excision & $\mathrm{U}$ & $\mathrm{U}$ \\
\hline
\end{tabular}

F: Female, M: Male, L-Left, R-Right, B-Bilateral, M-Multifocal, U: Unknown, mo: Month, yr: Year, NA: Not applicable

Six out of 34 (about 21\%) patients had multiple mass lesions in either one or bilateral breasts. Seven patients (about 21\%) had synchronous or metachronous nodal or non-mammary extranodal disease (Table 1). Ultrasonography usually showed a hypoechoic lesion in breast RDD. Radiological features were variable with some cases presenting as a benign lesion, such as fat necrosis [11], and most presenting suspicious for malignancy, as BIRADS 4 or $5[12,13]$. Occasionally, positron-emission tomography (PET) scan demonstrated a hypermetabolic lesion $[14,15]$. The histiologic differential diagnosis includes idiopathic granulomatous mastitis, granulomatous inflammation, Langerhans' histiocytosis, fibrous histiocytoma, and malignancy [4]. The pathophysiology remains uncertain. Recently, both infectious and immune mechanisms have been proposed [20] for breast RDD. Definitive association with a specific organism has not been identified so far. Foucar et al. reported that many patients showed serum polyclonal gammopathy and plasma cell proliferation. A subset of patients also manifested various immune disorders including autoimmune hemolytic anemia, immune arthritis and glomerulonephritis [21,22]. Cha and Fu $[11,15]$ reported that increased IgG4 plasma cell was observed, especially in breast RDD with prominent fibrosis. Correlation of breast RDD and IgG4 related sclerosing mastitis has been investigated. The outcomes and mechanism remain unclear [2329]. In addition, RDD has responded well to steroid treatment, which suggested that RDD may be related to immune dysfunction [30]. Further studies are needed to clarify the pathogenesis. Our case showed prominent hyalinizing fibrosis at the periphery of the lesion. No immunologic or infectious agents were identified.

RDD is considered an indolent, benign, reactive process with a histiocytic proliferation of unknown etiology. The majority of patients with RDD follow a variable, benign course with some patients experiencing recurrences, exacerbations or stable disease for years. The reported mortality is extremely low. The risk factors for a poor prognosis include older age, concurrent immunologic dysfunction, systemic diseases, and involvement of vital internal organs such as kidneys, lung and liver [1,24-27]. In rare cases, mass formation or infiltration caused by RDD can be a direct cause of death [26]. Spontaneous remission was only seen in one reported case, which happened 6 months after initial diagnosis [7]. One elderly female patient died of disseminated RDD with breast involvement 2 months after diagnosis [4]. Our patient was treated by surgical resection with positive surgical margins. The patient was followed up for at least three years. No recurrence was observed. Currently, there are no guidelines for treating RDD. The majority of extranodal lesions are treated surgically. Based on our literature review, 28 of 34 $(82 \%)$ patients were treated with a surgical excision (Table 1 ). Short term post-operative follow up is necessary as disease recurrences occur. Patients with normal immune function and no coexisting systemic diseases may be returned to routine care. We conclude that RDD is a benign clinical process with histiocytic proliferation showing hallmark finding of emperipolesis. The RDD lesion demonstrates positivity of S100 and CD68, negativity of CD1a by immunohistochemical study. Current common treatment modality is surgical resection with rare recurrence [31-35].

\section{Ethical Approval}

The presented investigations and the publication of data comply with ethical rules of East Carolina University and general rules of experimentation with humans.

\section{Declaration of Conflicting Interests}

There are no potential conflicts of interest with respect to the research, authorship, and/or publication of this article.

\section{Financial Support and Sponsorship}

The author(s) received no financial support for the research, authorship, and/or publication of this article.

\section{References}

1. Rosai T, Dorfman RF (1969) Sinus histiocytosis with massive lymphadenopathy. A newly recognized benign clinicopathological entity. Arch Pathol 87(1): 63-70.

2. Eisen RN, Buckley PJ, Rosai J (1990) Immunophenotypic characterization of sinus histiocytosis with massive lymphadenopathy (Rosai-Dorfman disease). Semin Diagn Pathol 7(1): 74-82.

3. Foucar E, Rosai J, Dorfman R (1990) Sinus histiocytosis with massive lymphadenopathy (Rosai-Dorfman disease): review of the entity. Semin Diagn Pathol 7(1): 19-73.

4. Green I, Dorfman RF, Rosai J (1997) Breast involvement by extranodal Rosai Dorfman disease: report of seven cases. Am J Surg Pathol 21(6): 664-668.

5. Mac-Moune LF, Lam WY, Chin CW, Ng WL (1994) Cutaneous Rosai-Dorfman disease presenting as a suspicious breast mass. J Cutan Pathol. 21(4): 377-382.

6. Perera AS, Keleher AJ, Nath M (2007) Rosai-Dorfman disease presenting as a male breast mass. Am Surg 73(3): 294-295.

7. Bansal P, Chakraborti S, Krishnanand G, Bansal R (2010) Rosai-Dorfman disease of the breast in a male: a case report. Acta Cytol 54(3): 3493-3452. 
8. Pérez-Guillermo M, Sola-Pérez J, Rodríguez-Bermejo M (1993) Malacoplakia and Rosai-Dorfman disease: two entities of histiocytic origin infrequently localized in the female breast--the cytologic aspect in aspirates obtained via fine-needle aspiration cytology. Diagn Cytopathol 9(6): 698-704.

9. Ng SB, Tan LH, Tan PH (2000) Rosai-Dorfman disease of the breast: a mimic of breast malignancy. Pathology 32(1): 10-15.

10. Baladandapani P, Hu Y, Kapoor K, Merriam L, Fisher PR (2012) Rosai-Dorfman disease presenting as multiple breast masses in an otherwise asymptomatic male patient. Clin Radiol 67(4): 393-395.

11. Cha YJ, Yang WI, Park SH, Koo JS (2012) Rosai-Dorfman Disease in the breast with increased IgG4 expressing plasma cells: a case report. Korean J Pathol 46(5): 489-493.

12. Silva DBB, Lopes-Costa PV, Pires CG, Moura CS, Borges RS, et al. (2007) Rosai-Dorfman disease of the breast mimicking cancer. Pathol Res Pract 203(10): 741-744.

13. Kuzmiak CM, Koomen M, Lininger R, Pisano E (2003) Rosai-Dorfman disease presenting as a suspicious breast mass. AJR Am J Roentgenol 180(6): 1740-1742.

14. Wu YC, Hsieh TC, Kao CH, Chang HW, Wang CH, et al. (2010) A mimic of breast lymphoma: extranodal Rosai-Dorfman disease. Am J Med Sci 339(3): 282-284.

15. Fu L, Liu M, Song Z, Xu B, Tian J, et al. (2012) 18F-fluoro-deoxyglucose positron emission tomography/computed tomography scan findings in Rosai-Dorfman disease with IgG4positive plasma cell infiltration mimicking breast malignancy: a case report and literature review. J Med Case Rep 30(6): 411.

16. Morkowski JJ, Nguyen CV, Lin P, Farr M, Abraham SC, et al. (2010) Rosai-Dorfman disease confined to the breast. Ann Diagn Pathol. 14(2): 81-87.

17. Hammond LA, Keh C, Rowlands DC (1996) Rosai-Dorfman disease in the breast. Histopathology 29(6): 582-584.

18. Soares FA, Llorach-Velludo MA, Andrade JM (1999) Rosai-Dorfman's disease of the breast. Am J Surg Pathol 2393): 359-360.

19. Hummel P, Waisman J, Chhieng D, Yan Z, Cohen JM, et al. (1999) Fineneedle aspiration cytology of Rosai-Dorfman disease of the breast: A case report. Diagn Cytopathol 21(4): 287-291.

20. Foucar E, Rosai J, Dorfman RF, Eyman JM (1984) Immunologic abnormalities and their significance in sinus histiocytosis with massive lymphadenopathy. Am J Clin Pathol 82(5): 515-525.

21. Chen TD, Lee LY (2011) Rosai-Dorfman disease presenting in the parotid gland with features of IgG4-related sclerosing disease. Arch Otolaryngol Head Neck Surg 137(7): 705708.
22. Roberts SS, Attanoos RL (2010) IgG4+ Rosai-Dorfman disease of the lung. Histopathology 56(5): 662-664.

23. Liu L, Perry AM, Cao W, Smith LM, Hsi ED, et al. (2013) Relationship between Rosai-Dorfman disease and IgG4-related disease: study of 32 cases. Am J Clin Pathol 140(3): 395-402.

24. McClain KL, Natkunam Y, Swerdlow SH (2004) Atypical cellular disorders. Hematology Am Soc Hematol Educ Program, pp. 283-296.

25. Paulli M, Rosso R, Kindl S, Boveri E, Marocolo D, et al. (1992) Immunophenotypic characterization of the cell infiltrate in five cases of sinus histiocytosis with massive lymphadenopathy (Rosai-Dorfman disease). Hum Pathol 23(6): 647-654.

26. Foucar E, Rosai J, Dorfman RF (1984) Sinus histiocytosis with massive lymphadenopathy. An analysis of 14 deaths occurring in a patient registry. Cancer 54(9): 1834-1840.

27. Chen J, Tang H, Li B, Xiu Q (2011) Rosai-Dorfman disease of multiple organs, including the epicardium: An unusual case with poor prognosis. Heart Lung 40(2): 168-171.

28. Tenny SO, McGinness M, Zhang D, Damjanov I, Fan F, et al. (2011) Rosai-Dorfman disease presenting as a breast mass and enlarged axillary lymph node mimicking malignancy: a case report and review of the literature. Breast J 17(5): 516-520.

29. Mantilla JG, Goldberg-Stein S, Wang Y (2016) Extranodal Rosai-Dorfman Disease: Clinicopathologic Series of 10 Patients with Radiologic Correlation and Review of the Literature. Am J Clin Pathol 145(2): 211221.

30. Pulsoni A, Anghel G, Falcucci P, Matera R, Pescarmona E, et al. (2002) Treatment of sinus histiocytosis with massive lymphadenopathy (Rosai-Dorfman disease): report of a case and literature review. Am J Hematol 69(1): 67-71.

31. Gwin K, Cipriani N, Zhang X, Schmidt R, Hyjek E, et al. (2011) Bilateral breast involvement by disseminated extranodal Rosai-Dorfman disease. Breast J 17(3): 309-311.

32. Parkin CKE, Keevil C, Howe M, Maxwell AJ (2015) Rosai-Dorfman disease of the breast. BJR Case Rep 1(1): 20150010.

33. Zhou Q, Ansari U, Keshav N, Davis F, Cundiff M, et al. (2016) Extranodal manifestation of Rosai-Dorfman disease in the breast tissue. Radiol Case Rep 11(3): 125-128.

34. Delaney EE, Larkin A, MacMaster S, Sakhdari A, DeBenedectis CM, et al. (2017) Rosai Dorfman Disease of the Breast. Cureus 9(4): e1153.

35. El-Attrache B, Gluck B, Heimann A, Kapenhas E (2018) A rarity in breast pathology: First recurrent male case of Rosai-Dorfman disease. Int J Surg Case Rep 52: 137-139.

\section{Your next submission with Juniper Publishers will reach you the below assets}

- Quality Editorial service

- Swift Peer Review

- Reprints availability

- E-prints Service

- Manuscript Podcast for convenient understanding

- Global attainment for your research

- Manuscript accessibility in different formats

( Pdf, E-pub, Full Text, Audio)

- Unceasing customer service

Track the below URL for one-step submission

https://juniperpublishers.com/online-submission.php 